\title{
GIPR rS10423928 and bone mineral density in postmenopausal women in Shanghai
}

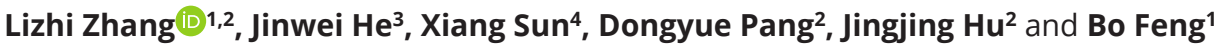 \\ 1Department of Endocrinology, Shanghai East Hospital, Tongji University School of Medicine, Shanghai, China \\ ${ }^{2}$ Department of Endocrinology, Jiading Branch of Shanghai General Hospital, Shanghai Jiao Tong University School of Medicine, Shanghai, China \\ ${ }^{3}$ Department of Osteoporosis and Bone Disease, Shanghai Jiao Tong University Affiliated Sixth People's Hospital, Shanghai, China \\ ${ }^{4}$ Shanghai Institute of Technology, Shanghai, China
}

Correspondence should be addressed to B Feng: fengbodfyy@tongji.edu.cn

\begin{abstract}
We demonstrated previously that there is a correlation between glucagon-like peptide-1 (GLP-1) single-nucleotide polymorphism (SNP) and bone mineral density in postmenopausal women. Both GLP-1 and glucose-dependent insulinotropic peptide are incretins. The glucose-dependent insulinotropic peptide receptor (GIPR) SNP rs10423928 has been extensively studied. However, it is not clear whether GIPR gene mutations affect bone metabolism. The aim of this study was to investigate the association between rs10423928 and bone mineral density in postmenopausal women in Shanghai. rs10423928 was detected in 884 postmenopausal women in Shanghai, and the correlation between the GIPR SNP and bone mineral density was assessed. The dominant T/T genotype of rs 10423928 was found to be related to the bone mineral density of the femoral neck $(P=0.035)$. Overall, our findings indicate that the dominant T/T genotype of $\mathrm{rs} 10423928$ in postmenopausal women is significantly associated with a higher bone mineral density and that the T/T genotype exerts a bone-protective effect.
\end{abstract}

\author{
Key Words \\ - osteoporosis \\ - glucose-dependent \\ insulinotropic peptide \\ - single-nucleotide \\ polymorphism \\ - polymorphism \\ - haplotype \\ - bone mineral density
}

\section{Introduction}

Postmenopausal osteoporosis is related to aging and has serious health effects. Bone mineral density (BMD) is the most common diagnostic indicator of osteoporosis, and $60-80 \%$ of BMD variations are determined by genetic factors (1). Some drugs commonly used to regulate blood sugar, such as glucagon-like peptide-1 (GLP-1) receptor agonists and DPP-4 inhibitors (DPP-4is), can inhibit bone resorption and improve bone formation $(2,3,4,5,6,7)$. GLP-1 is a DPP-4 substrate; other substrates of DPP-4, such as glucose-dependent insulinotropic peptide (GIP) and GLP-2, can also affect bone metabolism, promote bone formation, or reduce bone resorption by osteoclasts $(8,9,10,11)$.

Glucose-dependent insulinotropic peptide (GIP) plays a biological role by binding to the corresponding GIP receptor (GIPR) on the cell surface. GIPR is located on chromosome 19 q13.3 and comprises 14 exons, having the size of approximately $14 \mathrm{~kb}$ (12). GIPR, which is widely expressed in various tissues and organs, is also expressed in extra-pancreatic cells, such as osteoblasts and the small intestine $(13,14)$. Mutations in GIPR may lead to abnormal GIPR expression and function, which may be related to the risk of osteoporosis. Furthermore, phenotypic differences in the human body and susceptibility to drugs or diseases may be related to single-nucleotide polymorphisms (SNPs). There are 13 SNPs in GIPR. Among them, rs10423928 has been studied extensively. It involves the replacement of thymine with an adenine base (T/A) (15). Research on rs 10423928 mainly focuses on type 2 diabetes and impaired insulin secretion $(16,17)$. In this study, we screened the CHBS (Genetic Variation Database of Han Nationality Population in Beijing, China) for GIPR SNP rs10423928 using second-stage HapMap data (ftp://ftp. ncbi.nlm.nih.gov/hapmap/). 
Table 1 Basic information of the patients enrolled in this study. Continuous variables with a normal distribution are represented by the mean \pm S.D. $(x \pm S)$, and data with a non-normal distribution are represented by the median and interquartile range.

\begin{tabular}{l} 
Characteristics \\
\hline Age (years) \\
Height $(\mathrm{cm})$ \\
Weight $(\mathrm{kg})$ \\
BMI $\left(\mathrm{kg} / \mathrm{m}^{2}\right)$ \\
Blood calcium (mmol/L) \\
Blood phosphorus (mmol/L) \\
Albumin (g/L) \\
Alkaline phosphatase $(\mathrm{U} / \mathrm{L})$ \\
Creatinine $(\mu \mathrm{mol} / \mathrm{L})$ \\
25(OH)D $\left(\mathrm{ng} / \mathrm{mL}^{2}\right)$ \\
Parathyroid hormone (pmol/L) \\
$\beta$-Collagen-specific sequence $(\mathrm{ng} / \mathrm{L})$ \\
L1-4 BMD $\left(\mathrm{g} / \mathrm{cm}^{2}\right)$ \\
Neck BMD $\left(\mathrm{g} / \mathrm{cm}^{2}\right)$ \\
Total BMD $\left(\mathrm{g} / \mathrm{cm}^{2}\right)$ \\
\hline
\end{tabular}

Age $<$ 60 years $(n=224)$
$54.9 \pm 5.8$
$156.2 \pm 5.2$
$57.6 \pm 8.4$
$23.6 \pm 3.3$
$2.34(2.27-2.40)$
$1.14(1.03-1.23)$
$47.00(46.00-49.00)$
$69.00(56.00-80.00)$
$54.00(49.00-60.75)$
$20.92(16.28-26.86)$
$40.65(32.82-53.34)$
$403.50(223.00-5630)$
$0.894(0.806-0.992)$
$0.758(0.708-0.848)$
$0.801(0.727-0.895)$

\begin{tabular}{ccll}
\hline Age $\geq \mathbf{6 0}$ years $(n=660)$ & & \multicolumn{1}{c}{$\boldsymbol{P}$} \\
\hline $71.3 \pm 7.4$ & & 0.00 \\
$152.0 \pm 5.4$ & & 0.00 \\
$55.2 \pm 8.5$ & & 0.027 \\
$23.9 \pm 3.5$ & & 0.497 \\
$2.32(2.26-2.39)$ & & 0.718 \\
$1.12(1.01-1.23)$ & & 0.700 \\
$46.00(44.00-48.00)$ & & 0.008 \\
$72.00(60.00-90.00)$ & & 0.004 \\
$59.00(52.00-66.00)$ & & 0.00 \\
$21.36(15.56-27.97)$ & & 0.87 \\
$42.37(31.63-56.22)$ & & 0.128 \\
$366.00(216.75-551.00)$ & & 0.68 \\
$0.859(0.773-0.968)$ & & 0.008 \\
$0.692(0.623-0.761)$ & & 0.00 \\
$0.742(0.662-0.817)$ & & 0.00 \\
\hline & &
\end{tabular}

Both GLP-1 and GIP are incretins. Previously, we demonstrated a correlation between GLP-1 receptor gene $(G L P-1 R)$ polymorphisms and BMD in postmenopausal women in Shanghai, China (18). Therefore, we aimed at elucidating whether there is a correlation between GIP/GIPR and BMD and whether GIPR mutations affect the effects of GIP/GIPR.

\section{Materials and methods}

\section{Subjects}

The study was approved by the Ethics Committee of the Sixth People's Hospital, Shanghai Jiaotong University (2014-KY-001(K)). Han women who are being treated for osteoporosis at Shanghai Sixth People's Hospital were enrolled in this study. All subjects signed informed consent forms. BMD and other clinical data were analyzed.

The inclusion criteria were as follows: (i) natural menopause for more than 1 year and (ii) no anti-osteoporotic treatment (except for calcium and vitamin D supplementation). The exclusion criteria were any disease that affects bone metabolism and use of medication, except for GLP-1 analogs or DPP4 inhibitors.

We included 907 postmenopausal women in this study; however, in order to minimize selection bias, some subjects were excluded, some samples were contaminated, were of poor quality, or were not successfully typed after one failure. Finally, 884 samples from postmenopausal women (mean age: $67.2 \pm 10.0$ years) were subjected to SNP detection. The average menopausal age of the 884 postmenopausal women was 47.41 years, and $90 \%$ of them had osteopenia/osteoporosis and 307 women had a history of fractures. These 307 women were ruled out of diseases and external factors that affect bone metabolism, accounting for approximately $34.73 \%$ of the participants.

\section{SNP detection}

Tag SNPs were selected based on the International Human Genome Haplotype Program (International HapMap

Table 2 Information related to SNP sites in the GLP-1R and GIPR genes.

\begin{tabular}{llc}
\hline SNPs & Chromosome position \\
\cline { 1 - 1 } rs2268657 & 39020542 \\
rs2295006 & 46182304 \\
rs3765467 & 46182304 \\
rs6923761 & 39055485 \\
rs1042044 & 39041502 \\
rs2268641 & 39050266 \\
rs4714210 & 39055485 \\
rs10423928 & 46182304 \\
\hline
\end{tabular}

\begin{tabular}{l} 
SNP property \\
\hline Intron 1 \\
Nonsynon_exon2 \\
Nonsynon_exon4 \\
Nonsynon_exon5 \\
Nonsynon_exon7 \\
Intron 12 \\
3'-UTR_exon13 \\
Intron 12
\end{tabular}

\begin{tabular}{c}
\hline Alleles \\
\hline $\mathrm{C} / \mathrm{T}$ \\
$\mathrm{G} / \mathrm{A}$ \\
$\mathrm{G} / \mathrm{A}$ \\
$\mathrm{G} / \mathrm{A}$ \\
$\mathrm{C} / \mathrm{A}$ \\
$\mathrm{C} / \mathrm{T}$ \\
$\mathrm{G} / \mathrm{A}$ \\
$\mathrm{T} / \mathrm{A}$ \\
\hline
\end{tabular}

\begin{tabular}{c}
\hline HWE $P$ value \\
\hline 0.1902 \\
0.7755 \\
0.5521 \\
1 \\
1 \\
0.5249 \\
0.1432 \\
0.9107 \\
\hline
\end{tabular}

\begin{tabular}{c}
\hline MAF in CHBS \\
\hline 0.34 \\
0.07 \\
0.23 \\
0.01 \\
0.47 \\
0.39 \\
0.29 \\
0.20 \\
\hline
\end{tabular}

\begin{tabular}{l}
\hline MAF in this study \\
\hline 0.326 \\
0.06 \\
0.255 \\
0.01 \\
0.46 \\
0.417 \\
0.317 \\
0.208
\end{tabular}

CHBS, Genetic Variation Database of Han Nationality Population in Beijing, China; HWE, Hardy-Weinberg equilibrium; MAF, minimum mean allele frequency; Non-synon, non-synonymous.

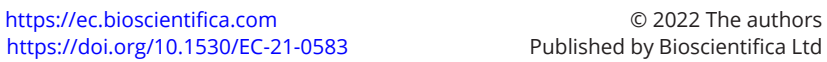


Project (ftp://ftp.ncbi.nlm.nih.gov/hapmap/), with the following criteria: (i) minimum mean allele frequency (MAF) > 0.01; (ii) coefficient of linkage disequilibrium (LD) $\mathrm{r}^{2}>0.8$; and (iii) SNPs reported in a previous genomewide association study. The GIPR rs10423928 locus was characterized.

Amplification was achieved by performing multiplex PCR. Each measurable allele locus-ligation product was obtained after two ligation reactions. The raw data files were analyzed using the GeneMapper 4.1
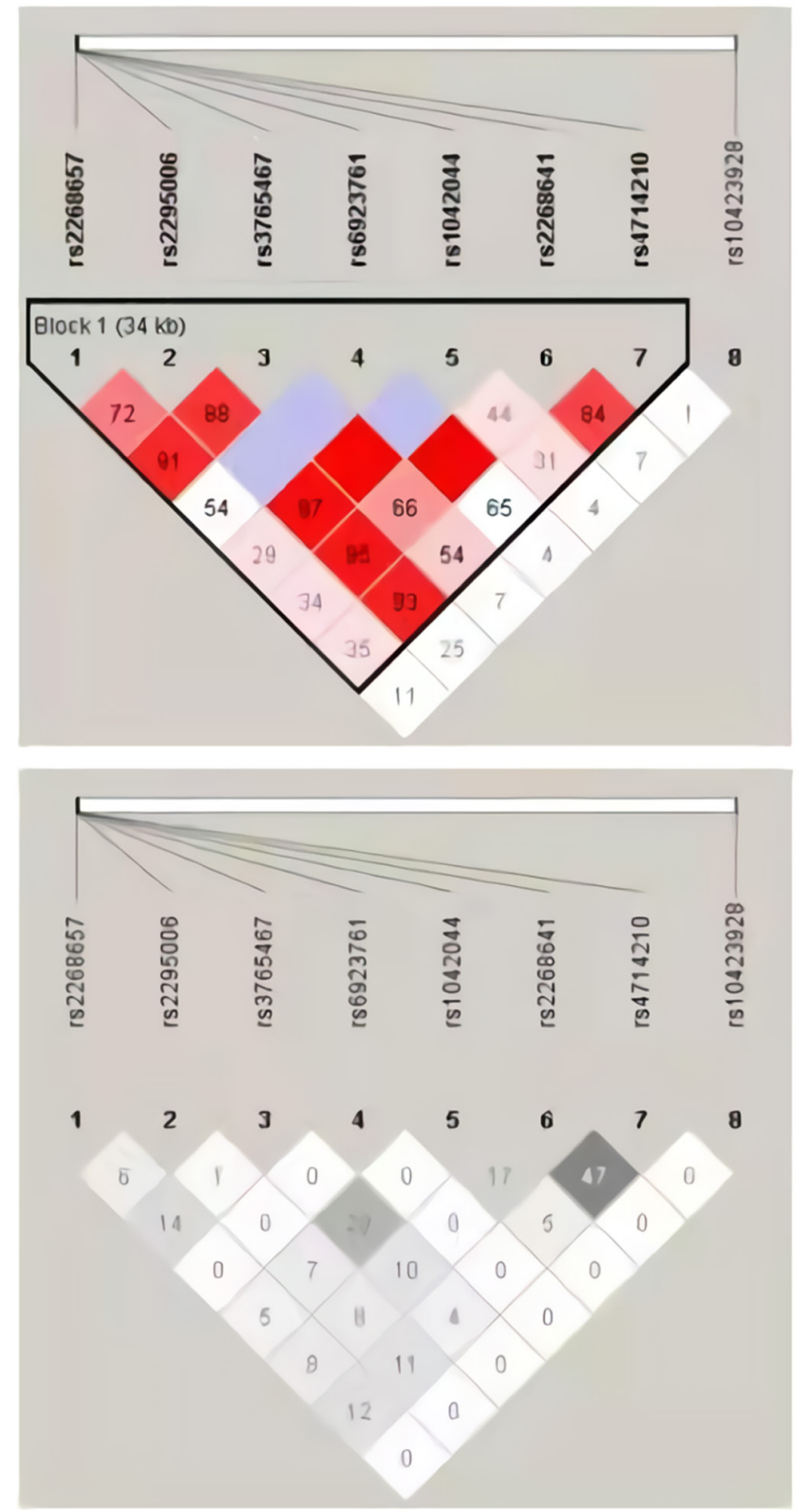

Figure 1

No linkage disequilibrium relationship between GIPR SNP rs10423928 and GLP-1R SNPS. software (Applied Biosystems). The iMLDR ${ }^{\circledast}$ multiple SNP typing system (Shanghai Tianhao Biotechnology Co., Ltd., Shanghai, China) (19) was used to classify the GIPR rs10423928 SNP site in 884 samples from postmenopausal women.

\section{BMD}

The BMD of the lumbar spine 1-4 (L1-4), left femoral neck, and total hip was measured for postmenopausal female subjects, expressed in $\mathrm{g} / \mathrm{cm}^{2}$, using dualenergy x-ray absorptiometry (GE Lunar Prodigy Bone Densitometer, Little Chalfont, UK). Following strict quality-control requirements, the instrument was tested once daily before use with a standard phantom to evaluate the stability of the system. The coefficient of variation of the lumbar spine, left femoral neck, and total hip BMD measurements was $1.39,2.22$, and $0.70 \%$, respectively.

\section{Statistical analysis}

Statistical analysis was performed using the SPSS software (version 24.0; SPSS, Inc.). Continuous variables with a normal distribution are expressed as mean \pm S.D. $(x \pm s)$. Continuous variables between groups were compared using the $t$-test. Chi-squared tests were used to compare categorical variables. The Haploview software (version 4.2) was used to calculate the D' value and LD coefficient $\left(\mathrm{r}^{2}\right)$ between SNPs. After adjusting for age, linear regression was used to assess the relationship between GIPR SNP and BMD in postmenopausal women. $P<0.05$ was considered to reflect a statistically significant difference.

\section{Results}

To determine the effect of aging on osteoporosis in elderly women, the subjects were divided into different age groups according to a recognized age classification system ( $<60$ and $\geq 60$ years) (20). Table 1 shows the baseline characteristics of these subjects. No significant difference was detected in the serum calcium and phosphorus levels between the groups. Alkaline phosphatase (AKP) was significantly higher in the group aged $\geq 60$ years than in the group aged $<60$ years $(P=0.004)$. The BMD in the group aged $\geq 60$ years was lower than that in the group aged $<60$ years $(P<0.001)$.

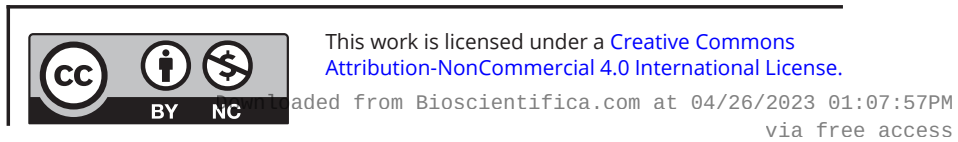


Table 3 Clinical data corresponding to GIPR rs10423928 SNP locus in postmenopausal women.

\begin{tabular}{|c|c|}
\hline $\begin{array}{l}\text { rs10423928 } \\
\text { genotype }\end{array}$ & $n$ \\
\hline $\mathrm{T} / \mathrm{T}$ & 556 \\
\hline $\mathrm{A} / \mathrm{T}$ & 289 \\
\hline $\mathrm{A} / \mathrm{A}$ & 39 \\
\hline
\end{tabular}

\begin{tabular}{l} 
Age (years) \\
\hline $67.1 \pm 10.1$ \\
$67.6 \pm 9.8$ \\
$65.4 \pm 9.7$ \\
\hline
\end{tabular}

\begin{tabular}{|c|c|}
\hline Height $(\mathrm{cm})$ & Weight $(\mathrm{kg})$ \\
\hline $152.7 \pm 5.5$ & $55.5 \pm 8.9$ \\
\hline $153.7 \pm 5.7$ & $56.1 \pm 8.2$ \\
\hline $152.0 \pm 5.8$ & $56.5 \pm 6.1$ \\
\hline
\end{tabular}

\section{Allele frequencies}

The GIPR rs10423928 locus was analyzed. The genotype distribution met the Hardy-Weinberg equilibrium. The MAF of rs10423928 in the CHBS (representing the national database) is $20 \%$, and in the present study, it was $20.8 \%$ (Table 2). There was no linkage disequilibrium relationship between rs10423928 and GLP-1R SNPs $\left(0.908<D^{\prime}<1\right)$ (Fig. 1).

Table 3 shows the clinical data corresponding to rs10423928 in postmenopausal women. The rs10423928 locus has three genotypes: T/T, A/T, and A/A. Among them, the $\mathrm{T} / \mathrm{T}$ genotype was detected in 556 patients (62.9\%), the A/T genotype was detected in 289 patients (32.7\%), and the A/A genotype was detected in 39 patients (4.4\%).

Based on the linear regression analysis, the rs10423928 locus was unrelated to age, height, weight, BMI, Ca, P, PTH, AKP, ALB, and Scr ( $P>0.05$; Table 4$)$. A close correlation was noted between the rs10423928 locus and BMD. The T/T genotype positively correlated with the femoral neck BMD and Ward's triangle area BMD in postmenopausal women $(P<0.05$; Table 5).

\section{Discussion}

Genome-wide association analysis has confirmed that BMD is associated with multiple genetic-susceptibility regions $(21,22)$. Correlations between vitamin $\mathrm{D}$ receptor

\begin{tabular}{|c|c|c|c|}
\hline BMI $\left(\mathrm{kg} / \mathrm{m}^{2}\right)$ & $\begin{array}{l}\text { L1-4 BMD } \\
\left(\mathrm{g} / \mathrm{cm}^{2}\right)\end{array}$ & $\begin{array}{c}\text { Femoral neck } \\
\text { BMD }\left(\mathrm{g} / \mathrm{cm}^{2}\right)\end{array}$ & $\begin{array}{c}\text { Total hip BMD } \\
\left(\mathrm{g} / \mathrm{cm}^{2}\right)\end{array}$ \\
\hline $23.8 \pm 3.6$ & $0.877 \pm 0.161$ & $0.708 \pm 0.120$ & $0.755 \pm 0.132$ \\
\hline $23.7 \pm 3.3$ & $0.896 \pm 0.155$ & $0.728 \pm 0.119$ & $0.769 \pm 0.130$ \\
\hline $24.5 \pm 3.0$ & $0.882 \pm 0.148$ & $0.719 \pm 0.124$ & $0.773 \pm 0.143$ \\
\hline
\end{tabular}

gene polymorphisms and osteoporosis were discovered in 1994 (23). Subsequently, >100 gene polymorphisms related to bone metabolism regulation have been identified.

Currently, there are no relevant data from clinical research showing that GIPR polymorphism is related to bone metabolism. In our previous research, we found that GLP-1R SNP is related to bone metabolism. Both GIP and GLP-1 are incretins, and both of them are related to glucose and lipid metabolism. The purpose of our research was to determine whether there is a correlation between GIPR SNP and bone metabolism.

Some clinical and animal studies have shown that GIPR has a relationship with bone metabolism. Patients with type 2 diabetes express low levels of GIPR or have defective GIPR $(24,25)$. In GIPR knockout mice, the cortical bone becomes thinner, the number of endosteal osteoclasts increases, and BMD decreases, indicating that there is a decrease in bone strength and bone quality (11). GIPR knockout mice exhibited an increased plasma calcium concentration after feeding, indicating that GIP may play a role in calcium homeostasis (26). GIP can guide the absorption of skeletal nutrients through the gutbone axis and regulate bone turnover. There is a close relationship between bone turnover and intestinal hormones $(27,28,29)$.

GIP can affect bone metabolism directly and indirectly $(30,31,32,33,34)$, and it plays a biological role by binding

Table 4 Linear-regression analysis of correlations between the GIPR gene rs10423928 locus and ordinary index in postmenopausal women.

\begin{tabular}{|c|c|c|c|c|}
\hline \multirow[b]{2}{*}{ Mark } & \multicolumn{2}{|c|}{ Dominant } & \multicolumn{2}{|c|}{ Recessive } \\
\hline & $\beta$ & $P$ & $\beta$ & $P$ \\
\hline Age & 0.220 & 0.753 & -1.806 & 0.271 \\
\hline Height & 0.842 & 0.176 & -1.038 & 0.449 \\
\hline Weight & 0.597 & 0.527 & 0.795 & 0.702 \\
\hline BMI & 0.009 & 0.982 & 0.747 & 0.377 \\
\hline $\mathrm{Ca}$ & -0.012 & 0.443 & -0.000 & 0.998 \\
\hline$P$ & 0.024 & 0.376 & 0.049 & 0.102 \\
\hline PTH & -1.870 & 0.208 & -7.173 & 0.312 \\
\hline AKP & -0.619 & 0.158 & -0.564 & 0.594 \\
\hline ALB & -0.448 & 0.839 & -2.703 & 0.620 \\
\hline Scr & 0.090 & 0.939 & -2.095 & 0.424 \\
\hline
\end{tabular}

\begin{tabular}{ccc}
\hline \multicolumn{2}{c}{ Addictive } \\
\hline$\beta$ & & $P$ \\
\cline { 1 - 1 }-0.075 & & 0.898 \\
0.431 & & 0.403 \\
0.522 & & 0.504 \\
0.112 & & 0.725 \\
-0.009 & & 0.514 \\
0.023 & & 0.192 \\
-2.228 & & 0.076 \\
-0.511 & & 0.168 \\
-0.647 & 0.731 \\
-0.023 & 0.817 \\
\hline
\end{tabular}

$\beta$, regression coefficient.

https://ec.bioscientifica.com

https://doi.org/10.1530/EC-21-0583 (c) 2022 The authors Published by Bioscientifica Ltd

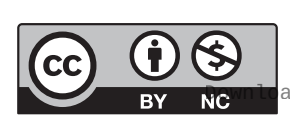

This work is licensed under a Creative Commons Attribution-NonCommercial 4.0 International License. ded from Bioscientifica.com at 04/26/2023 01:07:57PM via free access 
Table 5 Linear-regression analysis of correlations between the GIPR gene rs10423928 locus and BMD in postmenopausal women.

\begin{tabular}{l}
\hline BMD \\
\hline L1 \\
L2 \\
L3 \\
L4 \\
L1-2 \\
L1-3 \\
L1-4 \\
L2-3 \\
L2-4 \\
L3-4 \\
Neck \\
Ward's \\
Troch \\
Inter \\
Total
\end{tabular}

\begin{tabular}{cc}
\hline & Dom \\
\hline$\beta$ & 0.014 \\
0.017 \\
0.021 \\
0.026 \\
-0.019 \\
-0.023 \\
-0.021 \\
-0.010 \\
-0.010 \\
0.010 \\
0.018 \\
0.019 \\
0.009 \\
0.017 \\
0.014
\end{tabular}

\begin{tabular}{c}
\hline \multicolumn{1}{c}{ Recessive } \\
\hline$\beta$ \\
\hline-0.004 \\
0.002 \\
0.000 \\
0.015 \\
0.018 \\
0.039 \\
0.050 \\
0.038 \\
0.050 \\
0.044 \\
0.007 \\
0.016 \\
0.005 \\
0.032 \\
0.017 \\
\hline
\end{tabular}

\section{sive}

$P$
0.180
0.150
0.123
0.053
0.296
0.271
0.331
0.603
0.611
0.581
$0.035^{a}$
$0.033^{a}$
0.278
0.140
0.118

a $P \leq 0.05$.

$\beta$, regression coefficient.

to the corresponding GIPR on the cell surface. GIPR SNP rs 10423928 has been studied frequently. It consists of the major allele $\mathrm{T}$ and the minor allele A. Individuals with the $\mathrm{T} / \mathrm{T}$ genotype who consume a high-carbohydrate/low-fat diet have a lower risk of type 2 diabetes (16). The minor allele A is associated with an impaired insulin secretion stimulated by glucose and GIP and a decreased BMI, lean body mass, and waist circumference (17). In the present study, we found that the BMD in the group aged $\geq 60$ years was lower than that in the group aged $<60$ years $(P<0.001)$. This indicates that with age, the bone mass of women decreases $(35,36)$. We neither find that the genotypes of rs10423928 are associated with BMI and body weight nor did we find an association of each genotype with $\mathrm{Ca}, \mathrm{P}$, PTH, and AKP.

Studies have found that there is a strong linkage disequilibrium between the SNPs rs10423928 and rs1800437 (Glu 354Gln located in exon 10, E354Q) of the GIPR locus $\left(\mathrm{r}^{2}=0.99\right)$. rs 1800437 can reduce the expression of GIPR in carriers $(37,38)$. In the Danish Osteoporosis Prevention Study (39), rs1800437 was associated with BMD and fracture risk. Compared with those with the major allele $\mathrm{G}$, the femoral neck BMD and total hip bone BMD of women with the minor allele $\mathrm{C}$ were significantly reduced. Women who are homozygous for the variant $\mathrm{C}$ allele have an increased risk of non-vertebral fractures. Our study revealed that the dominant $\mathrm{T} / \mathrm{T}$ genotype of rs 10423928 in postmenopausal women was significantly associated with a higher BMD of the femoral neck. This indicated that the T/T genotype of GIP has a protective effect against osteoporosis.
Our study was not a prospective study but a crosssectional cohort study. We found that the dominant $\mathrm{T} / \mathrm{T}$ genotype of rs10423928 was significantly associated with a higher BMD, unlike the other genotypes in postmenopausal women. This does not indicate that this genotype can prevent or warn of osteoporosis. The T/T genotype seems to have a bone-protective effect, but the mechanism needs to be further explored.

Taken together, our study showed that the dominant $\mathrm{T} / \mathrm{T}$ genotype of rs10423928 in postmenopausal women is significantly associated with a higher BMD and that the $\mathrm{T} / \mathrm{T}$ genotype seems to have a bone-protective effect.

Declaration of interest

The authors declare that there is no conflict of interest that could be perceived as prejudicing the impartiality of the research reported.

\section{Funding}

This work was supported by the Pudong New Area Health and Family Planning Commission Fund Project (grant number PWZzk2017-12).

\section{Ethical statement}

The authors are accountable for all aspects of the work in ensuring that questions related to the accuracy or integrity of any part of the work are appropriately investigated and resolved. The study was approved by the Ethics Committee of the Sixth People's Hospital, Shanghai Jiaotong University (2014-KY-001(K)).

\section{Author contribution statement}

(i) Conception and design: L Zhang, B Feng; (ii) Administrative support: B Feng; (iii) Provision of study materials or patients: J He; (iv) Collection and assembly of data: J He, L Zhang, X Sun; (v) Data analysis and interpretation: 
X Sun, W He, Dongyue Pang, Jingjing Hu. All authors contributed to writing the manuscript and approving the final manuscript and agreed to be accountable for all aspects of the work in ensuring that questions related to the accuracy or integrity of any part of the work are appropriately investigated and resolved.

\section{References}

1 Peacock M, Turner CH, Econs MJ \& Foroud T. Genetics of osteoporosis. Endocrine Reviews 200223 303-326. (https://doi.org/10.1210/ edrv.23.3.0464)

2 Josse RG, Majumdar SR, Zheng Y, Adler A, Bethel MA, Buse JB, Green JB, Kaufman KD, Rodbard HW, Tankova T, et al. Sitagliptin and risk of fractures in type 2 diabetes: results from the TECOS trial. Diabetes, Obesity and Metabolism 201719 78-86. (https://doi. org/10.1111/dom.12786)

3 Ma X, Meng J, Jia M, Bi L, Zhou Y, Wang Y, Hu J, He G \& Luo X. Exendin-4, a glucagon-like peptide-1 receptor agonist, prevents osteopenia by promoting bone formation and suppressing bone resorption in aged ovariectomized rats. Journal of Bone and Mineral Research 201328 1641-1652. (https://doi.org/10.1002/jbmr.1898)

4 Meng J, Ma X, Wang N, Jia M, Bi L, Wang Y, Li M, Zhang H, Xue X, Hou Z, et al. Activation of GLP-1 receptor promotes bone marrow stromal cell osteogenic differentiation through $\beta$-catenin. Stem Cell Reports 20166 579-591. (https://doi.org/10.1016/j. stemcr.2016.02.002)

5 Monami M, Dicembrini I, Antenore A \& Mannucci E. Dipeptidyl peptidase- 4 inhibitors and bone fractures: a meta-analysis of randomized clinical trials. Diabetes Care 201134 2474-2476. (https:// doi.org/10.2337/dc11-1099)

6 Trujillo JM \& Nuffer W. GLP-1 receptor agonists for type 2 diabetes mellitus: recent developments and emerging agents. Pharmacotherapy 201434 1174-1186. (https://doi.org/10.1002/phar.1507)

7 Yamada C, Yamada Y, Tsukiyama K, Yamada K, Udagawa N, Takahashi N, Tanaka K, Drucker DJ, Seino Y \& Inagaki N. The murine glucagon-like peptide-1 receptor is essential for control of bone resorption. Endocrinology 2008149 574-579. (https://doi.org/10.1210/ en.2007-1292)

8 Glorie L, D'Haese PC \& Verhulst A. Boning up on DPP4, DPP4 substrates, and DPP4-adipokine interactions: logical reasoning and known facts about bone related effects of DPP4 inhibitors. Bone 2016 92 37-49. (https://doi.org/10.1016/j.bone.2016.08.009)

9 Mabilleau G. Incretins and bone: friend or foe? Current Opinion in Pharmacology 201522 72-78. (https://doi.org/10.1016/j. coph.2015.03.007)

10 Mabilleau G, Perrot R, Mieczkowska A, Boni S, Flatt PR, Irwin N \& Chappard D. Glucose-dependent insulinotropic polypeptide (GIP) dose-dependently reduces osteoclast differentiation and resorption. Bone 201691 102-112. (https://doi.org/10.1016/j.bone.2016.07.014)

11 Mieczkowska A, Irwin N, Flatt PR, Chappard D \& Mabilleau G. Glucose-dependent insulinotropic polypeptide (GIP) receptor deletion leads to reduced bone strength and quality. Bone 201356 337-342. (https://doi.org/10.1016/j.bone.2013.07.003)

12 Yamada Y, Hayami T, Nakamura K, Kaisaki PJ, Someya Y, Wang CZ, Seino S \& Seino Y. Human gastric inhibitory polypeptide receptor: cloning of the gene (GIPR) and cDNA. Genomics 199529 773-776. (https://doi.org/10.1006/geno.1995.9937)

13 Fujita Y, Wideman RD, Asadi A, Yang GK, Baker R, Webber T, Zhang T, Wang R, Ao Z, Warnock GL, et al. Glucose-dependent insulinotropic polypeptide is expressed in pancreatic islet alpha-cells and promotes insulin secretion. Gastroenterology 2010138 1966-1975. (https://doi. org/10.1053/j.gastro.2010.01.049)

14 Baggio LL \& Drucker DJ. Biology of incretins: GLP-1 and GIP. Gastroenterology 2007132 2131-2157. (https://doi.org/10.1053/j. gastro.2007.03.054)
15 Wang GJ, Yang P \& Xie HG. Gene variants in noncoding regions and their possible consequences. Pharmacogenomics 20067 203-209. (https://doi.org/10.2217/14622416.7.2.203)

16 Sonestedt E, Lyssenko V, Ericson U, Gullberg B, Wirfalt E, Groop L \& Orho-Melander M. Genetic variation in the glucose-dependent insulinotropic polypeptide receptor modifies the association between carbohydrate and fat intake and risk of type 2 diabetes in the Malmo Diet and Cancer Cohort. Journal of Clinical Endocrinology and Metabolism 201297 E810-E818. (https://doi.org/10.1210/jc.2011-2444)

17 Lyssenko V, Eliasson L, Kotova O, Pilgaard K, Wierup N, Salehi A, Wendt A, Jonsson A, De Marinis YZ, Berglund LM, et al. Pleiotropic effects of GIP on islet function involve osteopontin. Diabetes 201160 2424-2433. (https://doi.org/10.2337/db10-1532)

18 Zhang L, He J, Sun X, Luo X, Zeng J, He W, Liu X \& Feng B. Relationship between glucagon-like peptide-1 receptor gene polymorphism and bone mineral density in postmenopausal women in Shanghai. Annals of Palliative Medicine 20209 1732-1741. (https:// doi.org/10.21037/apm-19-396)

19 Zhang XY, He JW, Fu WZ, Liu YJ \& Zhang ZL. Associations of serum osteocalcin and polymorphisms of the osteocalcin gene with bone mineral density in postmenopausal and elderly Chinese women. Journal of Nutrigenetics and Nutrigenomics 20169 231-242. (https://doi. org/10.1159/000452130)

20 Chou KL \& Chi I. Successful aging among the young-old, old-old, and oldest-old Chinese. International Journal of Aging and Human Development 200254 1-14. (https://doi.org/10.2190/9K7T-6KXMC0C6-3D64)

21 Rivadeneira F, Styrkársdottir U, Estrada K, Halldórsson BV, Hsu YH, Richards JB, Zillikens MC, Kavvoura FK, Amin N, Aulchenko YS, et al. Twenty bone-mineral-density loci identified by large-scale metaanalysis of genome-wide association studies. Nature Genetics 200941 1199-1206. (https://doi.org/10.1038/ng.446)

22 Styrkarsdottir U, Halldorsson BV, Gretarsdottir S, Gudbjartsson DF, Walters GB, Ingvarsson T, Jonsdottir T, Saemundsdottir J, Center JR, Nguyen TV, et al. Multiple genetic loci for bone mineral density and fractures. New England Journal of Medicine 2008358 2355-2365. (https://doi.org/10.1056/NEJMoa0801197)

23 Morrison NA, Qi JC, Tokita A, Kelly PJ, Crofts L, Nguyen TV, Sambrook PN \& Eisman JA. Prediction of bone density from vitamin D receptor alleles. Nature 1994367 284-287. (https://doi. org/10.1038/367284a0)

24 Holst JJ, Gromada J \& Nauck MA. The pathogenesis of NIDDM involves a defective expression of the GIP receptor. Diabetologia 1997 40 984-986. (https://doi.org/10.1007/s001250050779)

25 Meier JJ, Hücking K, Holst JJ, Deacon CF, Schmiegel WH \& Nauck MA Reduced insulinotropic effect of gastric inhibitory polypeptide in first-degree relatives of patients with type 2 diabetes. Diabetes 200150 2497-2504. (https://doi.org/10.2337/diabetes.50.11.2497)

26 Tsukiyama K, Yamada Y, Yamada C, Harada N, Kawasaki Y, Ogura M, Bessho K, Li M, Amizuka N, Sato M, et al. Gastric inhibitory polypeptide as an endogenous factor promoting new bone formation after food ingestion. Molecular Endocrinology 200620 1644-1651. (https://doi.org/10.1210/me.2005-0187)

27 Xie D, Zhong Q, Ding KH, Cheng H, Williams S, Correa D, Bollag WB, Bollag RJ, Insogna K, Troiano N, et al. Glucose-dependent insulinotropic peptide-overexpressing transgenic mice have increased bone mass. Bone 200740 1352-1360. (https://doi.org/10.1016/j.bone.2007.01.007)

28 Bollag RJ, Zhong Q, Ding KH, Phillips P, Zhong L, Qin F, Cranford J, Mulloy AL, Cameron R \& Isales CM. Glucose-dependent insulinotropic peptide is an integrative hormone with osteotropic effects. Molecular and Cellular Endocrinology 2001177 35-41. (https:// doi.org/10.1016/s0303-7207(01)00405-1)

29 Xie D, Cheng H, Hamrick M, Zhong Q, Ding KH, Correa D, Williams S, Mulloy A, Bollag W, Bollag RJ, et al. Glucose-dependent insulinotropic polypeptide receptor knockout mice have altered bone turnover. Bone 200537 759-769. (https://doi.org/10.1016/j.bone.2005.06.021)

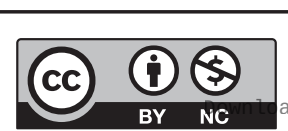

This work is licensed under a Creative Commons Attribution-NonCommercial 4.0 International License. ded from Bioscientifica.com at 04/26/2023 01:07:57PM 
30 Bollag RJ, Zhong Q, Phillips P, Min L, Zhong L, Cameron R, Mulloy AL, Rasmussen H, Qin F, Ding KH, et al. Osteoblast-derived cells express functional glucose-dependent insulinotropic peptide receptors. Endocrinology 2000141 1228-1235. (https://doi.org/10.1210/ endo.141.3.7366)

31 Zhong Q, Itokawa T, Sridhar S, Ding KH, Xie D, Kang B, Bollag WB, Bollag RJ, Hamrick M, Insogna K, et al. Effects of glucose-dependent insulinotropic peptide on osteoclast function. American Journal of Physiology: Endocrinology and Metabolism 2007292 E543-E548. (https://doi.org/10.1152/ajpendo.00364.2006)

32 Zaidi M, Shankar VS, Huang CL, Pazianas M \& Bloom SR. Amylin in bone conservation current evidence and hypothetical considerations. Trends in Endocrinology and Metabolism 19934 255-259. (https://doi. org/10.1016/1043-2760(93)90095-v)

33 Saxena R, Hivert MF, Langenberg C, Tanaka T, Pankow JS, Vollenweider P, Lyssenko V, Bouatia-Naji N, Dupuis J, Jackson AU, et al. Genetic variation in GIPR influences the glucose and insulin responses to an oral glucose challenge. Nature Genetics 201042 142-148. (https:// doi.org/10.1038/ng.521)

34 Ding KH, Zhong Q, Xu J \& Isales CM. Glucose-dependent insulinotropic peptide: differential effects on hepatic artery vs. portal vein endothelial cells. American Journal of Physiology: Endocrinology and Metabolism 2004 286 E773-E779. (https://doi.org/10.1152/ajpendo.00507.2003)
35 Cheng XG, Yang DZ, Zhou Q, Zhuo TJ, Zhang HC, Xiang J, Wang HF, Ou PZ, Liu JL, Xu L, et al. Age-related bone mineral density, bone loss rate, prevalence of osteoporosis, and reference database of women at multiple centers in China. Journal of Clinical Densitometry $2007 \mathbf{1 0}$ 276-284. (https://doi.org/10.1016/j.jocd.2007.05.004)

36 Chan GK \& Duque G. Age-related bone loss: old bone, new facts. Gerontology 200248 62-71. (https://doi.org/10.1159/000048929)

37 Fortin JP, Schroeder JC, Zhu Y, Beinborn M \& Kopin AS. Pharmacological characterization of human incretin receptor missense variants. Journal of Pharmacology and Experimental Therapeutics 2010332 274-280. (https://doi.org/10.1124/ jpet.109.160531)

38 Mohammad S, Patel RT, Bruno J, Panhwar MS, Wen J \& McGraw TE. A naturally occurring GIP receptor variant undergoes enhanced agonistinduced desensitization, which impairs GIP control of adipose insulin sensitivity. Molecular and Cellular Biology 2014 34 3618-3629. (https:// doi.org/10.1128/MCB.00256-14)

39 Torekov SS, Harslof T, Rejnmark L, Eiken P, Jensen JB, Herman AP, Hansen T, Pedersen O, Holst JJ \& Langdahl BL. A functional amino acid substitution in the glucose-dependent insulinotropic polypeptide receptor (GIPR) gene is associated with lower bone mineral density and increased fracture risk. Journal of Clinical Endocrinology and Metabolism 201499 E729-E733. (https://doi.org/10.1210/jc.2013-3766)

Received in final form 22 December 2021

Accepted 14 January 2022

Accepted Manuscript published online 14 January 2022
This work is licensed under a Creative Commons Attribution-NonCommercial 4.0 International License. ded from Bioscientifica.com at 04/26/2023 01:07:57PM 